
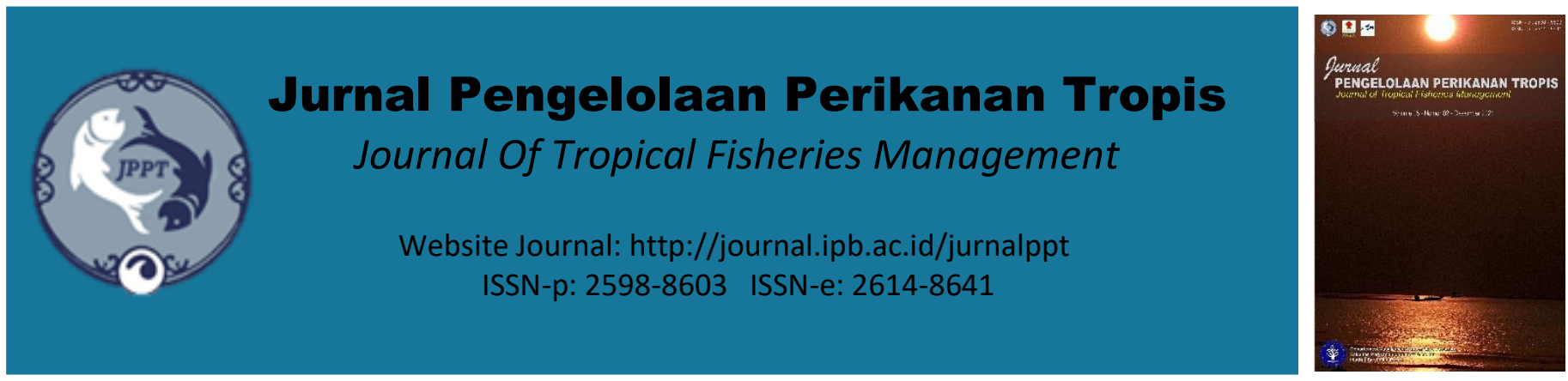

\title{
Sustainability Strategy for Small-Scale Fisheries Management: Case Study in Semarang City Coastal, Indonesia
}

\author{
(Strategi Keberlanjutan Pengelolaan Perikanan Skala Kecil: Studi Kasus di Pesisir Kota Semarang, \\ Indonesia)
}

\section{Jamaludin Malik $^{1, *}$, Hendi Kristiana ${ }^{1}$}

\author{
${ }^{1}$ Department of Marine Affairs and Fisheries, Central Java Province, Jl. Imam Bonjol No. 134 Semarang 50132
}

\section{INFO ARTIKEL}

\section{Article History}

Recevied: 2 Maret 2021

Accepted: 14 September 2021

\section{Keywords: \\ small-scale fisheries, strategy, sustainable fisheries management}

\section{Kata Kunci: \\ perikanan skala kecil, strategi, pengelolaan perikanan berkelanjutan}

\section{Corresponding Author}

Jamaludin Malik, Dinas Kelautan dan Perikanan Provinsi Jawa Tengah, Jl. Imam Bonjol No. 134 Semarang 50132.

Email: jamesmely@gmail.com

\begin{abstract}
Small-scale fisheries in Semarang City have complex problems. In the existing condition, overcapacity and over-exploited have occurred. At the level of sustainability, each aspect of management (environment, fish resources, facilities and technology, socioeconomic, institutional and governance) is a challenge to achieve sustainable fisheries management in Semarang City. This study aims to formulate a sustainability strategy for small-scale fisheries management in Semarang City. The sustainability strategies for small-scale fisheries management in Semarang City that can be formulated are: (1) increasing efforts to conserve fish resources and ecosystems; (2) increasing the income and welfare of fishermen and poverty alleviation; (3) increase the productivity of capture fisheries; (4) improve law enforcement/fisheries regulations.
\end{abstract}

\begin{abstract}
ABSTRAK
Perikanan skala kecil di Kota Semarang memiliki permasalahan yang kompleks. Pada kondisi yang ada telah terjadi kelebihan kapasitas penangkapan dan tangkap lebih. Pada tataran keberlanjutan, setiap aspek pengelolaan (lingkungan, sumberdaya ikan, sarana dan teknologi, sosial ekonomi, serta tata kelola dan kelembagaan) merupakan tantangan untuk mencapai pengelolaan perikanan berkelanjutan di Kota Semarang. Penelitian ini bertujuan untuk merumuskan strategi keberlanjutan pengelolaan perikanan skala kecil di Kota Semarang. Strategi keberlanjutan pengelolaan perikanan skala kecil di Kota Semarang yang dapat dirumuskan adalah: (1) meningkatkan upaya pelestarian/konservasi sumberdaya ikan dan ekosistem; (2) meningkatkan pendapatan dan kesejahteraan nelayan serta pengentasan kemiskinan; (3) meningkatkan produktivitas perikanan tangkap; (4) meningkatkan penegakan hukum/regulasi perikanan.
\end{abstract}

\section{INTRODUCTION}

The purpose of collecting exploited fish stock data is to develop credible stock valuations. Sufficient information, allows for an evaluation of management strategies for stocks, provides guidance on future management decisions. However, due to lack of data, many fisheries management agencies have difficulty evaluating management strategies (Ives and Scandol 2012). A number of alternative management strategies, including the use of fishing gear with more selective measures and total effort were evaluated for their impact on the sustainability of fish stocks, economic benefits and biological resilience as discussed by Ives et al. (2013).

Small-scale fisheries in Semarang City have complex problems. The development of the number of fishermen who do fishing business with the use of increased effort and overcapacity has occurred and the production of catches that tends to decrease and indicates overexploited. This condition is coupled with the level of 
sustainability of each aspect of management tecnology, sosioeconomic and institutional and govermance) built from leverage attributes on the sustainability dimension is a challenge in smallscale fisheries management in Semarang City going forward. By knowing the status of fisheries resources and the status of sustainability in the existing conditions, making it a challenge to realize sustainable fisheries management in Semarang City.

The laws and regulations that govern and influence the conditions of small scale fisheries in Semarang City will determine the direction of the policy going forward. This policy direction is a need or future program plan for small scale fisheries management in Semarang City. For this reason, the formulation of sustainability strategies for small-scale fisheries management in Semarang City is very important. The fisheries management strategy should be accepted by all stakeholders as argued by Mardle et al. (2004). The "grand strategy" approach is useful in fisheries management (Bailey 2015). This is used to evaluate the usefulness of fisheries management from the five recommended principles, namely: (1) begins with a goal; (2) ecological approach; (3) the importance of tactics; (4) using practical solutions and (5) the importance of integration. This study aims to formulate a sustainability (environment, fish resources, facilities and strategy for small-scale fisheries management in Semarang City.

\section{RESEARCH METHODS}

\section{Time and Study Site}

The study was conducted for 4 months, October 2020 to January 2021. The study site in the coastal waters of Semarang City, Central Java Province, which is part of the North Coast of Central Java and also part of the Fisheries Management Area 712.

\section{Data Collection}

The data used in this study are primary and secondary data. Primary data were obtained from survey, interviews and questionnaires. Primary data collection is intended to determine the real conditions in the field. While secondary data as a support is obtained from the results of literature studies, documentation or reports. Secondary data used include statistics on capture fisheries for the last ten years available (2010-2019); study and Regional Regulation on Zoning Plan for Coastal Areas and Small Islands (RZWP3K) of Central Java Province; regulatory documents; as well as other related research report.
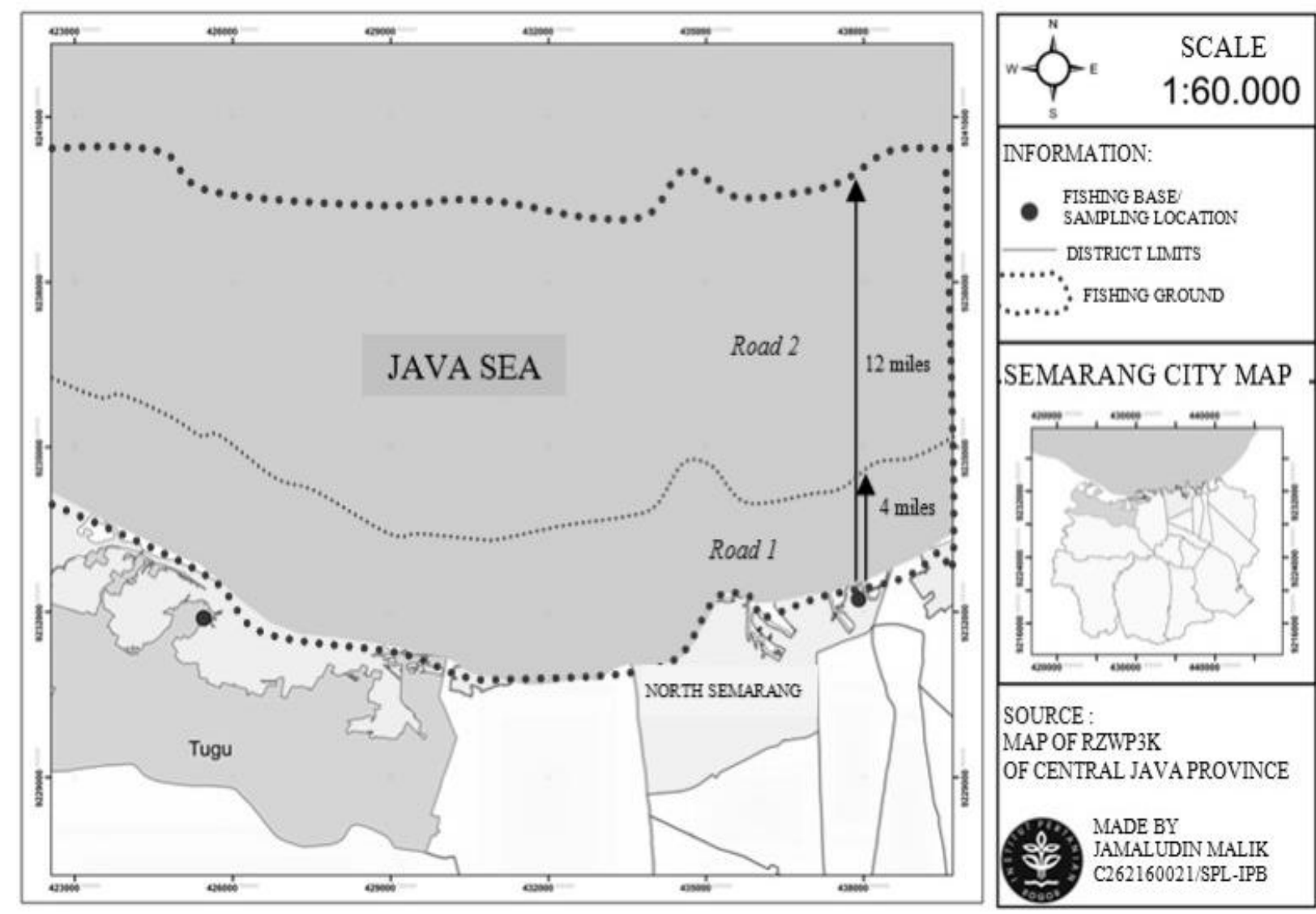

Figure 1. Map of study location 


\section{Data Analyses}

Fisheries management is inseparable from 3 aspects, namely aspects of fish resources and its ecosystem, socio-economic aspects of the community in the utilization of fisheries resources and aspects of fisheries policy as stated by Charles (2001). The analysis of the sustainability strategy of small-scale fisheries management in this study was carried out by integrating the status of resources and status of management in the existing conditions (objective 1), optimization of resource utilization (objective 2) and strategic fisheries management policies (objective 3 ). The result is a formulation of a small-scale sustainability management strategy which is a general objective in this study.

\section{RESULTS AND DISCUSSION}

Existing conditions contained in small-scale fisheries in Semarang City is an obstacle that must be overcome in the management of small-scale fisheries. Various optimization efforts must be made to overcome the existing conditions so that small-scale fisheries management in Semarang City can be sustainable. On the environmental aspect, the existing conditions that occur with coastal damage in the form of abrasion, rob and mangrove ecosystem damage, the optimization efforts that can be done to overcome the damage to the beach are:

1. Making the structure of coastal protective buildings as a hard solution, such as a breakwater, sea wall and groynes. These coastal protective structures can be installed in areas affected by coastal abrasion/erosion.

2. Using non-structural coastal protectors as soft solutions, such as planting mangroves in locations where mangrove ecosystems have been damaged for rehabilitation. Mangrove rehabilitation has a function as a protector of the beach and maintain the balance of coastal ecosystems to stay healthy. The ecosystem approach is the management of ecosystems and natural habitats for ecological sustainability, as well as the link between fulfilling human wellbeing and the health of environmental resources (Susilowatí 2013; Kenny et al. 2017). Consideration of ecosystems in fisheries management encourages the use of ecosystem indicators (Probst and Stelzenmuller 2015). Many fisheries managers use the amount of fish produced as an indicator of ecosystem health (Berkes et al. 2001). Management of fisheries with an ecosystem approach guarantees the sustainability of marine ecosystems and fisheries activities including the indirect effects of catches on the entire ecosystem (Link 2010).

3. Installation of pump housings to overcome the problem of tidal inundation that commonly occurs around coastal areas and settlements.

The condition of the degradation of fish resources in Semarang City Coastal is mostly caused by: (1) the status of the resource that has experienced overfishing; (2) high fishing pressure due to overcapacity; (3) stacking of fishing lanes on line 1 (0-4 miles); (4) the existence of Arad's operation as a capture that is not environmentally friendly. Optimization efforts undertaken to overcome the problem of damage to fish resources are:

1. Limitation of effort due to overcapacity, according to the solution offered by Berkes et al. (2001); Pomeroy (2011); Suman et al. (2018) by: (a) Prioritization of reductions carried out on capture units that are not environmentally friendly; (b) The transfer of fishing gear that is not environmentally friendly is replaced by fishing gear that is more environmentally friendly (more selective); (c) Permit for capture business (SIUP and SIPI) is limited; (d) Transfer of further fishing ground; (e) Transfer of fishing activities or livelihoods.

2. Temporarily closing the capture area on line 1 (0-4 miles).

3. The operation of fishing gear that is not environmentally friendly is carried out by a moratorium, where for 3 months each year a ban is placed on operations to provide opportunities for fish resources to recover. Besides that, mesh size regulation can also be applied, which is the use of minimum mesh size ( 2 inch).

In the aspect of facilities and technology, the existing condition is that the size of the ship used is below 5 GT and does not use fishing aids. In order to obtain optimal results, the optimization efforts undertaken related to improving aspects of this facility and technology are:

1. Increasing the ability of the fleet and fishing gear. The fishing fleet which was originally small in size (under 5 GT), must be increased to a larger size (10-30 GT) in order to reach a wider capture area, have a greater cruising range (up to the offshore area), operating time longer so you will get more catches.

2. Use of fishing aids. Fishing operations using fishing aids will get more effective and efficient results (Nurani et al. 2014). 
3. The use of more modern capture technology, such as: global positioning system (GPS), sonar, oceanographic satellite, echo sounder, fish finder and net recorder.

In the socio-economic aspect, the main obstacle that occurs in existing conditions is the lack of fishermen's income. To overcome the minimum income of fishermen who have an impact on poverty, optimization efforts that can be made so that fishermen's income increases and poverty can be alleviated are:

1. Adapt climate change to help get fishermen out of poverty.

2. Play an important role of women fishermen in small scale fisheries. They can play a role in fish processing and marketing activities; prepare supplies for fishing; making and repairing nets and other fishing gear; as happened in Britain (Frangoudes 2013), in Spain and Portugal (Frangoudes 2011); participate in group decision making (KUB) and fishing businesses, as happened in Northern Norway (Gerrard 2016).

3. Creating new/alternative livelihoods, including: cultivating green shellfish and milkfish; fishery product processing; processed fish traders; culinary sellers of fish cuisine; service provider for the repair and manufacture of nets/fishing gear, shipbuilding and machinery.

4. Activities that can provide added value. Marketing of fish catches and processed smallscale fishery products can provide added value to be more effective and innovative in the market through promotional activities in collaboration with scientists, local governments and industry, such as: fish bazaar and fisheries product exhibition as argeued by PascualFernandez et al. (2019).

In the institutional and governance aspects, the constraints that occur in the existing conditions are that fisheries regulations have not been effective and institutional mechanisms have not been optimal. Optimization efforts that can be done to overcome the existing obstacles in the institutional and governance aspects are:

1. Law enforcement (regulation) fisheries. Almost all small-scale fisheries need a different radical approach in the enforcement and compliance of rules (Berkes et al. 2001). Law enforcement can be improved through strengthening monitoring and supervision programs.

2. Better governance arrangements. Good smallscale fisheries governance requires transdisciplinary knowledge that integrates knowledge from various academic disciplines of stakeholders (Jentoft and Chuenpagdee 2019).

The perspective of sustainability in the perspective of integration of environmental and fish resources (ecological), socio-economic and institutional aspects in fisheries management is very important (Charles 2001; Adrianto et al. 2005).

\section{Sustainability of Small Scale Fisheries Management}

The sustainability of small-scale fisheries globally requires knowledge that integrates transdisciplinary. Transdisciplinary perspectives that combine ecosystem integrity, economic viability and social justice in fisheries management play an important role for the longterm sustainability and survival of fishing communities (Phillipson and Symes 2012; Kosamu 2014; Espinoza-Tenorio et al. 2015; Augustave 2019). Transdisciplinary thinking has been integrated into global sustainable development (SDG) goals. SDG is a transformative call throughout the world to act and improve good environmental conditions and human well-being by 2030 .

The goal of managing small-scale fisheries resources is directed at getting people to get safe food; fish can be seen as a source of protein (nutrition) to support human health and provide a healthy environment; opportunities for employment/livelihoods; increased income, welfare and poverty alleviation; so it must be managed properly. Contribution of small-scale fisheries to food security and security; occupation and livelihoods; and poverty alleviation; making it important to link small-scale fisheries with other sustainable development (SDG) goals, specifically SDG 1: without poverty; SDG 2: zero hunger; SDG 8: decent work and economic growth (Mc Conney et al. 2014; de Mattos et al. 2017).

\section{Contribution of Small Scale Fisheries to Food Security and Safety}

More than 120 million people worldwide depend directly on fishing and other fisheryrelated activities, including processing and trade (HLPE 2014). Of these, small-scale fisheries represent around $90 \%$, with most of them located in developing countries, including Indonesia (FAO 2014). Small-scale fisheries contribute at least $25 \%$ of the world's catch (Pauly and Zeller 2016), and unlike large-scale fisheries, almost all of these 
catches are for human consumption (World Bank et al. 2012). At the global level, increasing access to small-scale fisheries can be an important way to improve community food security, because most of the income in developing countries is used to meet food needs (Banerjee and Duflo 2007). The most recently available data, fish accounted for a significant amount of total protein available in many countries, as many as $21 \%$ in China, $23 \%$ in Japan, and 14\% in Norway (FAO 2016).

Fish caught in small-scale fisheries, in addition to being a source of protein (nutrition), can also be used as processed products that can provide a longer shelf life, so that it will guarantee the availability (security) of food. In addition it can also be processed in the form of fresh treatment that has been carried out weeding (removal of scales, stomach contents and gills) to eliminate the central contaminants, such as bacteria, viruses and protozoa (microbes) and maintained cleanliness and cold chain. Thus, fishery products will be produced in these small scale fisheries that meet sanitation and hygiene standards for food safety. The higher nutritional value of fish is recognized as an important aspect in building and maintaining food security, both at the local and national level (HLPE 2014; Isaacs 2016). The healthy ecosystems and sustainable use of fish resources are part of a sustainable food production system, as added by Foale et al. (2012). As such, small-scale fisheries are important in contributing to food security and security (HLPE 2014).

\section{Contribution of Small Scale Fisheries to Work/Livelihoods}

Small-scale fisheries with transdisciplinary knowledge that integrate various academic disciplines can contribute as a source of employment and income for coastal communities (Augustave 2019). Jobs or livelihoods intended are as cultivators, fishery product processors, fish collectors and fishery processed products, fish food culinary sellers, providers of fishing gear and workshop equipment, and other types of work related to the existence of small scale fisheries. This was confirmed by Mc Conney et al. (2014) who convey the importance of conservation and stewardship for small-scale fishermen to maintain their livelihoods and create new opportunities as alternatives without eroding the ecological basis.

\section{Contribution of Small Scale Fisheries to Poverty Alleviation}

Fisheries management that only focuses on resources, will result in marginalization of poor people which can cause problems in coastal communities (Muallil et al. 2013). Poverty is not only a matter of economic income, but a multidimensional phenomenon (Agarwala 2014). Understanding the motivation and behavior of fishermen is fundamental to managing the longterm sustainability of small-scale fisheries. However, the behavior and choices of fishermen are usually complex and consist of a series of economic, social and cultural considerations (Coulthard 2012). The social welfare approach as a solution to broaden and deepen our understanding of how values shape the behavior of small-scale fishermen. Through the economy, activities on small scale fisheries are created that can provide added value so as to increase income and welfare. Through social culture; able to change bad habits that cause poverty in smallscale fisheries such as wasteful and consumptive, lazy, easily complacent and difficult to accept innovation; with community empowerment and assistance through programs that synergize between the government, fishermen, industry and other stakeholders.

\section{Sustainability Strategy for Small Scale Fisheries Management}

The formulation of a small-scale fisheries management strategy in the City of Semarang is adjusted to the direction of the use of capture fisheries zones contained in Perda No. 13 of 2018 concerning Central Java Province RZWP3K 20182038. In Article 23 paragraph 3 of RZWP3K Regional Regulation it is explained that the direction for capture fisheries zones can be made by:

1. Utilize fish resources sustainably.

2. Carry out revitalization of productive and environmentally friendly fishing gear to increase catch production.

3. Rationalization of fishing areas so that the right location and the right season and does not interfere with fish spawning areas.

4. Increasing the capacity of fishing vessels.

5. Improve the abilities and skills of small fishermen.

6. Improve fish auction management.

7. Implement post-capture cold chain technology to maintain the quality of the catch.

There are provisions in spatial use in capture fisheries zones as follows:

a. Fishing activities must use environmentally friendly equipment.

b. Fishing activities must consider protecting habitat and fish populations. 
Table 1. Goals, policies, sustainability strategies, small-scale fisheries management programs

\begin{tabular}{|c|c|c|c|}
\hline Objective & Policy & Sustainability Strategy & Program \\
\hline \multirow[t]{2}{*}{$\begin{array}{l}\text { 1. To preserve } \\
\text { fish resources }\end{array}$} & $\begin{array}{l}\text { 1) Conservation of fish } \\
\text { resources }\end{array}$ & $\begin{array}{l}\text { (1) Increase efforts to } \\
\text { preserve/conserve fish } \\
\text { and ecosystem } \\
\text { resources }\end{array}$ & $\begin{array}{l}\text { a) Limitation of fishing gear that is not } \\
\text { environmentally friendly } \\
\text { b) Temporary area closure on line } 1(0-4 \text { miles }) \\
\text { c) Mangrove planting }\end{array}$ \\
\hline & $\begin{array}{l}\text { 2) Optimization of } \\
\text { fisheries institutions } \\
\text { and governance }\end{array}$ & $\begin{array}{l}\text { (2) Improve law } \\
\text { enforcement/fisheries } \\
\text { regulations }\end{array}$ & $\begin{array}{l}\text { a) Monitoring and supervision by fisheries } \\
\text { supervisors }\end{array}$ \\
\hline \multirow[t]{2}{*}{$\begin{array}{l}\text { 2. To increase } \\
\text { the income } \\
\text { and welfare of } \\
\text { fishermen }\end{array}$} & $\begin{array}{l}\text { 3) Increased income } \\
\text { and welfare of } \\
\text { fishermen }\end{array}$ & $\begin{array}{l}\text { (3) Increasing income and } \\
\text { welfare of fishermen } \\
\text { and poverty } \\
\text { alleviation }\end{array}$ & $\begin{array}{l}\text { a) Adaptation to climate change } \\
\text { b) Empowering fishermen and women /wives of } \\
\text { fishermen } \\
\text { c) Availability of new / alternative livelihoods }\end{array}$ \\
\hline & & $\begin{array}{l}\text { (4) Increasing fisheries } \\
\text { productivity }\end{array}$ & $\begin{array}{l}\text { a) Increasing the capability of the fleet and fishing } \\
\text { gear } \\
\text { b) Transfer of capture area }\end{array}$ \\
\hline
\end{tabular}

The formulation of sustainability strategies for small-scale fisheries management starts from determining management objectives, determining policies and formulating management strategies. The objectives of small-scale fisheries management are: 1) to preserve fish resources; 2) to increase the income and welfare of fishermen. To achieve this goal, policies that can be applied: (1) preservation of fish resources; (2) increase in income and welfare of fishermen; (3) optimization of fisheries institutions and governance. In determining the fish resources preservation policy, the sustainable management strategy that can be formulated is to increase efforts to conserve fish resources and the ecosystem. In determining the policies to increase fishermen's income and welfare, the sustainability management strategies are: (a) increasing the income and welfare of fishermen and poverty alleviation; (b) increase the productivity of capture fisheries through enhancing the capability of the fleet and fishing gear and the transfer of fishing ground. In determining the policy for institutional optimization and fisheries governance, the strategy for the sustainability of its management is to improve law enforcement/fisheries regulation.

To facilitate the understanding and implementation of policies and strategies for sustainability in small-scale fisheries management in Semarang City, the following are presented the objectives, policies, sustainability strategies and small-scale fisheries management programs (Table 1).

\section{CONCLUSION}

The formulation of sustainability strategies for small-scale fisheries management in Semarang City are: (1) Increasing efforts to preserve/ conserve fish resources and ecosystems; (2) Increasing the income and welfare of fishermen and poverty alleviation; (3) Increasing the productivity of capture fisheries; (4) Improve law enforcement/fisheries regulations.

\section{REFERENCES}

Adrianto L, Matsuda Y, Sakuma Y. 2005. Assessing local sustainability of fìsherìes system: a multicriteria participatory apprøach with the caseøf Yoron Island, Kagoshima prefecture, Japan. Mar Pol. 29: 9-23. doi:10.1016/j.marpol.2005.01.004.

Agarwala M. 2014. Assessing the relationship between human well-being and ecosystem services: a review of frameworks. Conserv Soc. 12: 437-449.

Augustave LC. 2019. Governing for Viability: The Case of Velondriake Locally Managed Marine Area in Madagascar. In: Chuenpagdee R, Jentoft S, editors. Transdisciplinarity for Small-Scale Fisheries Governance. Analysis and Practice. MARE Publication Series 21. Cham $(\mathrm{CH})$ : Springer Nature Switzerland AG. https://doi.org/10.1007/978-3-319-94938-3.

Bailey J. 2015. Adventures ìn cross-dìsciplìnary studìes: Grand strategy and fisheries management. Mar Pol. 63: 18-27. doi:10.1016/j.marpol.2015.09.013.

Banerjee AV, Duflo E. 2007. The economic lives of the poor. J Econ Perspect J Am Econ Assoc. 21: 141-167. https://doi.org/10.1257/jep.21.1.141.

Berkes F, Mahon R, Mc Conney P, Pollnac R, Pomeroy R. 2001. Managing small scale fisheries alternative directions and methods. Internatìonal development research centre.

Charles AT. 2001. Sustaínable Físhery System. Oxford (UK): Blackwell Scientific. 
Coulthard S. 2012. What does the debate around social wellbeing have to offer sustainable fisheries? Curr Opin Environ Sustain. 4: 358363.

de Mattos SMG, Wojciechowski MJ, Macnaughton AE. 2017. Implementing the small-scale fisheries guidelines: lessons from Brazilian clam fisheries. In: Jentoft $S$, Chuenpagdee R, Barragán-Paladines, editors. The small-scale fisheries guidelines: global implementation. New York (US): Springer. pp.473-494.

Espinoza-Tenorio A, Espejel I, Wolff M. 2015. From adoptíon to implementation? An academíc perspectíve on Sustaínable Fìsheríes Management in a developíng country. Mar Policy. 62: 252-260. http://dx.doi.org/10.1016/j.marpol.2015.09.00 1.

[FAO] Food and Agricultural Organizatíon. 2014. The state of world fisheries and aquaculture. Rome (IT): FAO.

[FAO] Food and Agriculture Organization of the United Nations. 2016. The state of world fisheries and aquaculture: contributing to food security and nutrition for all. Rome (IT): FAO.

Foale S, Adhuri D, Alino P. 2012. Food security and the coral triangle initiative. Mar Policy. 38: 174-183. https://doi.org/10.1016/j.marpol.2012.05.033.

Frangoudes K. 2011. Women's contribution in small scale fisheries in the European Union. In: Chuenpagdee (ed) World Small-Scale Fisheries Contemporary visions. Delft (NL): Eburon. pp 101-116.

Frangoudes K. 2013. Women in fisheries: a European perspective, note for the European Parliament, Policy Department B: Stuctural and Cohesion Policies. http://www.europarl. europa.eu/studies 2013. Accessed 10 May 2020.

Gerrard S. 2016. Kvinner i kystfiske - Gjester ved menns bord? In: Halrynjo S, Teigen M, editor. Ulik Like Stilling I Arbeidslivet. Oslo (NO) : Gyldendal Akademisk.

[HLPE] High Level Panel of Experts. 2014. Sustainable fisheries and aquaculture for food security and nutrition. Rome (IT) : A Report by the High Level Panel of Experts on Food Security and Nutrition, Committee on World Food Security (CFS).

Isaacs M. 2016. The humble sardine (small pelagics): fish as food or fodder. Agric Food Secur. 5: 27-35. https://doi.org/10.1186/s40066-016-0073-5.
Ives MC, Scandol JP. 2012. Biomas: a bioeconomíc modellíng and assessment system for fisheríes management strategy evaluation. Ecological Modelling. 249:

http://dx.døi.ørg/10.1016/j.ecolmodel.2012.07. 006.

Ives MC, Scandol JP, Greenvílle J. 2013. A bíoeconomíc management strategy evaluatíon før a multispecies, multífleet físhery facíng a world of uncertaínty. Ecological Modellíng. 256:

69-84. http://dx.døí.ørg/10.1016/j.ecolmodel.2013.01. 022.

Jentoft S, Chuenpagdee R. 2019. The quest for transdisciplinarity in small-scale fisheries governance. In: Chuenpagdee $\mathrm{R}$, Jentoft $\mathrm{S}$, editors. Transdisciplinarity for Small-Scale Fisheries Governance. Analysis and Practice. MARE Publication Series 21. Cham $(\mathrm{CH})$ : Springer Nature Switzerland AG. https://doi.org/10.1007/978-3-319-94938-3.

Kenny AJ, Campbell N, Koen-Alonso M, Pepin P, Diz D. 2017. Delivering sustaínable físheries through adoptíon of a rísk based frame work as part of an ecosystem approach to físheries management. Marine $\dot{P}$ olicy. httb://dx.doi.ørg/10.1016/j.marbøl.2017.05.01 8.

Kosamu IBM. 2014. Conditions for sustaínabílíty of small scale fisheries ín developíng countries. Fisheríes Research. 161: 365-373. http://dx.doi.org/10.1016/j.físhres.2014.09.002 Link JS. 2010. Ecosystem Based Fisheries Management: Confronting Trade offs. New York (US): Cambridge Universìty Press. 207p. Mardle S, Pascoe S, Herrero I. 2004. Management objective importance in físheríes: an evaluatíøn using the Analytíc Híerarchy Process (AHP). Envíronmental Management. 33(1): 1-11. doí:10.1007/s00267-003-3070-y.

Mc Conney P, Medeiros R, Pena M. 2014. Enhancing stewardship in small-scale fisheries: practices and perspectives. Too Big To Ignore (TBTI) and Centre for Resource Management and Environmental Studies, CERMES Technical Report 73. Cave Hill (BB): University of the West Indies.

Muallil RN, Mamauag SS, Cabral RB, CelesteDízon EO, Alíno PM. 2013. Status, trends and challenges in the sustaínability of small scale físheríes in the Philippines: Insíghts from FISHDA (Fishing Industríes Support in Handlíng Decisions Application) model. 
Marine Policy. 44: 212-221. http://dx.doi.org/10.1016/j.marpol.2013.08.02 6.

Nurani TW, Wisudo SH, Wahyuningrum PI, Arhatin RE. 2014. [Model of developing fishing aids in the sustainable use of tuna resources]. JIPI. 19(1): 57-65. [in Indonesian].

Pascual-Fernández JJ, Pita C, Hosupeit H, Said A, Rodrigues JG. 2019. Markets, distribution and value chains in small-scale fisheries: A special focus on Europe. In: Chuenpagdee R, Jentoft $\mathrm{S}$, editors. Transdisciplinarity for Small-Scale Fisheries Governance. Analysis and Practice. MARE Publication Series 21. Cham $(\mathrm{CH})$ : Springer Nature Switzerland AG. https://doi.org/10.1007/978-3-319-94938-3.

Pauly D, Zeller D. 2016. Catch reconstructions reveal that global marine fisheries catches are higher than reported and declining. Nat Commun. 7: 10-24.

Phillipson J, Symes D. 2012. Science for sustainable físheríes management: An interdisciplinary approach. Físheries Research. $\quad 139$ : 61-64. http://dx.doi.org/10.1016/j.fishres.2012.09.012

Pomeroy R. 2011. Managing overcapacity ín small scale físheríes ín Southeast Asía. Maríne Policy. 36: 520-527. døí:10.1016/j.marpol.2011.10.002.

Probst WN, Stelzenmuller V. 2015. A benchmarkíng and assessment framewørk to operationalíse ecologícal índícators based on tíme seríes analysís. Ecological Indicators. 55: 94-106. http://dx.doi.org/10.1016/ j.ecolind.2015.02.035.

Suman A, Satria F, Nugraha B, Priatna A, Amri K, Mahiswara. 2018. [Status of fish resource stocks in 2016 at WPP RI and alternative management]. Jurnal Kebijakan Perikanan Indonesia. 10(2): 107-128. [in Indonesian].

Susilowatí I. 2013. [Prospect of ecosystem-based fisheries management: an empirical study in Karimunjawa]. Jurnal Ekonomi Pembangunan. 14(1): 16-37. [in Indonesian].

World Bank, FAO, World Fish Center. 2012. Hidden harvest: the global contribution of capture fisheries. Report No. 66469-GLB. Washington DC (US): World Bank. 